\title{
Honey and Vitamin E Supplementation in Treating Human African Trypanosomiasis with Special Reference to TrypanosomaBrucei Albino Rats.
}

\author{
Amadi E. $\mathrm{N}^{1}$, Njoku O. O ${ }^{2}$, Okereke C. $\mathrm{N}^{3}$, Ndubuisi J. L ${ }^{4}$, Ekwealor, K. $\mathrm{U}^{5}$, \\ Edoga, C. $\mathrm{O}^{6}$ \\ ${ }^{I}$ Department of Zoology, NnamdiAzikiwe University, Awka, Anambra, NIGERIA. \\ ${ }^{2}$ Department of Biology, Federal University of Technology, Owerri, Imo, NIGERIA. \\ ${ }^{3}$ Department of Applied Biology, Ebonyi State University, Abakaliki, Ebonyi, NIGERIA. \\ ${ }^{4}$ Department of Botany, NnamdiAzikiwe University, Awka, Anambra, NIGERIA. \\ ${ }^{5}$ Department of Botany, NnamdiAzikiwe University, Awka, Anambra, NIGERIA. \\ 6Department of Zoology and Environmental Biology, University of Nigeria, Nsukka, Enugu, NIGERIA.
}

\begin{abstract}
Human African Trypanosomiasis (HAT) has been a serious topic of discussion due to its challenges it poses to livestock farmers and consumers of improperly cooked meats. Honey and vitamin E supplementation in treating African Trypanosomiasis with special reference to Trypanosomabrucei in infected albino rats was carried out in the Zoology department of NnamdiAzikiwe University, Awka. 36 albino rats were grouped into 18 infected and 18 uninfected male and female rats. Each of these 18 rats was further grouped into three subgroups each with six rats. The PCV of the infected rats has significant level at $t_{0.05}$ by 0.3179 while the Weight of the infected rats has significant level at $t_{0.05}$ by 3179.
\end{abstract}

\section{Introduction}

Sleeping Sickness also known as Human African Trypanosomiasis (HAT), is caused by Trypanosomabruceirhodensiense, prevalent in Eastern Africa and Trypanosomabruceigambiense, prevalent in Western Africa. Morphologically, both protozoans resemble but have drastic epidermiological features. Several hematophagousglossina called tsetse flies are vectors responsible for clinical transmission of the parasitic protozoan within the West African form. There is often delay and fatigue for some years due to the invasion of the cerebrospinal fluid and brain, hence there is witnessed toxemia, coma and death (8). The metacyclicstage transform into blood stage trypomastigote (long, slender forms) and divide by binary fission in the interstitial spaces at the site of bite wound. The building up of metabolic wastes and cell debris leads to the formation of a chancre (8). On the case where tsetse flies ingest more than one strain of trypanosome, there is the possibility of genetic exchange between the two strains, generating an increase in genetic diversity in an organism that may not have a sexual cycle (7). Tsetse flies inject over 40,000 metacyclic trypanosomes when they take a blood meal. The minimum infective dose for most hosts is $300-500$ organisms, although experimental animals have been infected with a single organism. Infection can also be acquired by eating raw meat from infected animals (3).

\section{Review OfLiterature}

Trypanosome is still a major obstacle to livestock production in Nigeria and the incidence rate is similar in young and adult animals (2). The packed cell volume only dropped slightly during the last four weeks while the mean body weight continued to increase. Similarly, the mean daily body temperature did not differ significantly from those of uninfected control rats (1). On the other hand infected laboratory rats developed an anaemic state shown by the haematocrit measurements. The open-field test showed to be less active and reactive as soon as the second week after infestation took place. A complementary histological study observed trypanosomes and inflammatory cells in the choroids plexusat the same period. The results are in favour of central nervous system functional disturbances. The observed weight loss is being discussed as beinga measure of the entry in the meningoencephalitic phase. The rat model reproduces neurological symptoms observed in the human disease and may prove to be useful for further neurological and therapeutic studies (4). Trypanosome infection as well as dietary supplement had a significant effect on lactation length. Milk off-take from trypanosome infected dose was significantly lower than that from the uninfected control group and there was a positive effect of plane of nutrition. The drop in milk off-take due to trypanosome infection was more severe in the supplemented group than in the group receiving a basal diet that was withdrawn from the experiment. The effect of trypanosome infection on live-weight was only noticeable during the first eight weeks of lactation and there was no significant effect on offspring growth rate unless the mother died (6). Plasma Total Protein (PTP), 
albumin and cholesterol concentrations were significantly reduced by the infection but were significantly increased by supplement that had higher dose of cholesterol and a tendency for a higher parasiteamia, and it was witnessed to have a lower resistance to infection (6).

\section{Materials And Methods}

18 infected male and female albino rats as well as 18 uninfected male and female albino rats were purchased from the Zoological garden of the University of Nigeria, Nsukka. They were acclimatized for experimentation at Zoology Department of NnamdiAzikiwe University, Awka, Nigeria. They were fed with pelleted feed from Vital feeds and Flour meals. This feed was supplemented with different doses of honey, vitamin $\mathrm{E}$ and a combination of honey and Vitamin E. the experiment was designed to have three groups that receive the supplements. The $1^{\text {st }}$ group has six infected rats fed with $1 \mathrm{~kg}$ Vital feeds $+100 \mathrm{ml}$ Honey. This has a control of another six uninfected rats fed equally with $1 \mathrm{~kg}$ Vital feeds $+100 \mathrm{ml}$ Honey. The $2^{\text {nd }}$ group has six infected rats fed with $1 \mathrm{~kg}$ Vital feeds $+50 \mathrm{ml}$ Vitamin E. This has a control of another six uninfected rats fed equally with $1 \mathrm{~kg}$ Vital feeds $+50 \mathrm{ml}$ Vitamin E. The $3^{\text {rd }}$ group has six infected rats fed with $1 \mathrm{~kg}$ Vital feeds + $50 \mathrm{ml}$ Vitamin $\mathrm{E}+100 \mathrm{ml}$ Honey. This has a control of another six uninfected rats fed equally with $1 \mathrm{~kg}$ Vital feeds $+50 \mathrm{ml}$ Vitamin E $+100 \mathrm{ml}$ Honey. Water was added ad libitum to all the groups.

\section{Results}

Tables 1: Results of the Packed Cell Volume, PCV (\%) of T. bruceiinfected and uninfected rats.

\begin{tabular}{|l|l|l|}
\hline 100ml Honey Supplement & PCV of Infected Rats & PCV of Uninfected Rats \\
\hline Day 1 & 32.50 & 36.00 \\
\hline Day 7 & 36.83 & 39.67 \\
\hline Day 14 & 40.50 & 42.83 \\
\hline Day 21 & 0.00 & 44.83 \\
\hline Average & $\mathbf{3 6 . 6 1}$ & $\mathbf{4 0 . 8 3}$ \\
\hline
\end{tabular}

\begin{tabular}{|l|l|l|}
\hline 50ml Vitamin E Supplement & PCV of Infected Rats & PCV of Uninfected Rats \\
\hline Day 1 & 33.83 & 3.50 \\
\hline Day 7 & 37.50 & 38.00 \\
\hline Day 14 & 40.50 & 42.83 \\
\hline Day 21 & 0.00 & 44.83 \\
\hline Average & $\mathbf{3 6 . 6 1}$ & $\mathbf{4 0 . 8 3}$ \\
\hline
\end{tabular}

\begin{tabular}{|l|l|l|}
\hline $\begin{array}{l}\text { 50ml Honey \& 50ml } \\
\text { Vitamin E Supplementation }\end{array}$ & PCV of Infected Rats & PCV of Uninfected Rats \\
\hline Day 1 & 32.00 & 36.50 \\
\hline Day 7 & 36.67 & 39.67 \\
\hline Day 14 & 40.83 & 41.83 \\
\hline Day 21 & 0.00 & 44.67 \\
\hline Average & $\mathbf{3 6 . 5 0}$ & $\mathbf{4 0 . 6 7}$ \\
\hline
\end{tabular}

Tables 2: Results of the weight (g) respectively of $T$. bruceiinfected and uninfected rats.

\begin{tabular}{|l|l|l|}
\hline 100ml Honey Supplement & Weight of Infected Rats & Weight of Uninfected Rats \\
\hline Day 1 & 152.67 & 125.17 \\
\hline Day 7 & 144.17 & 134.33 \\
\hline Day 14 & 135.50 & 144.00 \\
\hline Day 21 & 0.00 & 153.33 \\
\hline Average & $\mathbf{1 0 7 . 9 6}$ & $\mathbf{1 3 8 . 9 6}$ \\
\hline \multicolumn{2}{|l|}{} \\
\hline $\mathbf{5 0 m l}$ Vitamin E Supplement & Weight of Infected Rats & Weight of Uninfected Rats \\
\hline Day 1 & 151.67 & 122.50 \\
\hline Day 7 & 139.19 & 132.67 \\
\hline Day 14 & 131.00 & 143.17 \\
\hline Day 21 & 0.00 & 152.33 \\
\hline Average & $\mathbf{1 0 5 . 3 8}$ & $\mathbf{1 3 7 . 6 7}$ \\
\hline
\end{tabular}

\begin{tabular}{|l|l|l|}
\hline $\begin{array}{l}\text { 50ml Honey \& 50ml } \\
\text { Vitamin E Supplementation }\end{array}$ & Weight of Infected Rats & Weight of Uninfected Rats \\
\hline Day 1 & 143.17 & 127.33 \\
\hline Day 7 & 134.33 & 139.17 \\
\hline Day 14 & 126.00 & 150.67 \\
\hline Day 21 & 0.00 & 156.33 \\
\hline Average & $\mathbf{1 0 0 . 8 8}$ & $\mathbf{1 4 3 . 3 8}$ \\
\hline
\end{tabular}




\section{Discussion}

The results obtained in table 1 shows the Packed Cell Volume (PCV) of the experimental rats at days 1, 7, 14, and 21 of post infection. The lowest mean PCV count, 36.50\% was witnessed in Honey and Vitamin E supplementation of the infected rats, while the highest PCV count was $40.83 \%$ as seen in the honey treated supplementation. It was also found that Vitamin E increased the PCV count of the infected rats. However, table 2 represented the weight $(\mathrm{g})$ of the experimental rats at days $1,7,14$, and 21 of post infection. The lowest mean weight count, $100.88 \mathrm{~g}$ was witnessed in the infected rats treated with Honey and Vitamin E supplementation. On the other hand, the highest weight was witnessed in the $143.38 \mathrm{~g}$ of the uninfected rats treated with Vitamin E supplementation. Several research scientists channeled their attention in the last two decades to identify and standardize active ingredients to treat diseases militating against mankind. This brought the efficacy of honey and vitamin $\mathrm{E}$ in treating various parasitic diseases and as well management of sleeping sickness. In this study, we observed that the activities of honey and vitamin E to Trypanosomabrucei on infected rats were able to reduce the parasiteamia and extend the lifespan of the infected rats as was reported by (5) during their study. From this study, we concluded that honey and vitamin E have trypanocidal properties; anagelsic, antiinflammatory, anti-neoplstic and immunologic hence, they extend the lifespan of the Trypanosomabrucei infected rats by at least 6 days outside the usual 14 days mandate for death if untreated after infection. Despite the removal of the parasites from the blood, the T.brucei infected ratsstill died by day 20 suggesting that these parasites are enmity to life. However it is advising not to eat parboiled meat or half cooked meat, as it might be infected with Trypanosomabrucie which threatens man's healthy living.

\section{References}

[1]. Abenga, J.N., David, K. and Ezebuiro, F.A.G. (2005). Observation on the tolerance of young dogs (puppies) to infection with Trypanosomacongolence. African Journal of clinical and experimental Microbiology, 6(1) 28-33.

[2]. Abenga, J.N., Enwezor, F.N.C., Lawani, F.A.G., Osue, H.O. and Ikemereh, E.C.D. (2004). Trypanosome valence in cattle in Lere Area in Kaduna State, North Central Nigeria. Revue d' Elevageet de Medecineveterinaire des pays tropicaux, 57(1-2) 45-48.

[3]. Cattand, P. (1995). World Health Organization press release, WHO/73, 7October. 1994.

[4]. Darasaud, A., Bourdon, L., Chevrier, C., Kieta, M., Bouteille, M.B., Queyroy, A., Canini, F., Cespuglio, R., Dumas, M. and Bu guet, A. (2003). Clinical follow-up in the rat experimental model of African trypanosomiasis. Experimental Biology and Medicine, 228(11) 1335-1362.

[5]. Ekanem, J.T. and Yusuf, O.K. (2005). Activities of alkaline phosphatase, glutamate oxaloacetate triaminase and glutamate pyru vate transaminase in liver and serum of trypanosomiasis, sleeping sickness. Springer-verlag, Paris, 215-233.

[6]. Faye, D., Fall, A., Leak, S., Losson, B. and Geerts, S. (2005). Influence of an experimental Trypanosomacongolence infection and plane of nutrition on milk production and some biochemical parameters in West African dwarf goats. ActaTropica. 93 (3) $247-257$.

[7]. Kuboki, N., Sarurai, T.D., Cello, F., Grab, D.J., Suzuki, H., Sugimoto, C. and Igarashi, I. (2003). Loop-mediated isothermal amplification for detection of Africantrypanosomes. Journal of clinical microbiology, 41 (12) 5517-5524

[8]. Nishimura, K., Shima, K., Ohnishi, Y. and Yamasaki, S. (2005). Effects of heparin administration on Trypanosomabruceigambiense infection in rats. Journal of parasitology, 91(1): 219-222. 